Jurnal Info Kesehatan

Vol. 19, No. 2. December 2021, pp. 162-180

P-ISSN 0216-504X, E-ISSN 2620-536X

DOI: 10.31965/infokes.Vol19Iss2.558

Journal homepage:http://jurnal.poltekeskupang.ac.id/index.php/infokes

RESEAR C H

Open Access

\title{
The Prediction Number of Smear Acid Resistant Bacteria on Positive Pulmonary Tuberculosis Infection Disease at Madiun City in 2021 to 2025
}

\author{
Avicena Sakufa Marsanti ${ }^{1 a^{*}}$, Hanifah Ardiani ${ }^{1 b}$ \\ ${ }^{1}$ Department of Public Health, STIKES Bhakti Husada Mulia Madiun, Madiun, East Java, \\ Indonesia. \\ ${ }^{a}$ Email address: avicena.sm@gmail.com \\ ${ }^{\mathrm{b}}$ Email address: ardiani.hanifah@gmail.com
}

Received: 9 September 2021

Revised: 9 October 2021

Accepted: 12 December 2021

\begin{abstract}
Tuberculosis (TB) is an infectious disease caused by Mycobacterium Tuberculosis Bacillus. The disease spreads in the air when people contract TB bacteria, such as coughing or sneezing. The lack of ability to anticipate the incidence of Acid Resistant Bacteria Positive Pulmonary TB in Madiun City is affected by the time and number of events that have not been appropriately foreseen. There is no map of regional vulnerability based on the time of occurrence. Hence, the incidence of Acid Resistant Bacteria Positive Pulmonary TB in Madiun city increases, determined by the total number of cases in 6 health centers, seven hospitals, and one prison. In 2015, there were 174 cases, then in 2019, 706 cases. The objective of this study is to predict the number of Acid Resistant Bacteria Positive Pulmonary TB suffering in 2021-2025 based on gender, health centers, and prisons in Madiun City and the overall incidence of cases in 20152019 is then foreseen in 2021 to 2025 . This type of research is descriptive study research by employing Eviews with the ARIMA method. The population and samples in the study were all data of Acid Resistant Bacteria Positive Pulmonary TB case encompassing the sex of patients during 2015-2019 in Madiun City. The study aimed to predict the incidence of Acid Resistant Bacteria Positive Pulmonary TB in 2021-2025. The results of this study revealed the projection of Acid Resistant Bacteria Positive Pulmonary TB cases based on gender, health centers, hospitals, and prisons in Madiun City from 2020-2025, which experienced an increasing trend with the number of $933,992,1063,1120,1190$ incidences respectively. This study is recommended for relevant agencies or health services to perform preventive efforts by involving trained policymakers and Health Cadis, particularly in preventing TB disease and reducing the high rate of predicting positive pulmonary $\mathrm{TB}$ smear incidences in the future.
\end{abstract}

Keywords: Pulmonary TB, Acid Resistant Bacteria Positive, Prediction.

*Corresponding Author:

Avicena Sakufa Marsanti

Department of Public Health, STIKES Bhakti Husada Mulia Madiun, Madiun, East Java, Indonesia.

Email: avicena.sm@gmail.com

CThe Author(s) 2021. This article is distributed under the terms of the Creative Commons Attribution 4.0 International License (http://creativecommons.org/licenses/by/4.0/), which permits unrestricted use, distribution, and reproduction in any medium, provided you give appropriate credit to the original author(s) and the source, provide a link to the Creative Commons license, and indicate if changes were made. The Creative Commons Public Domain Dedication waiver (http://creativecommons.org/publicdomain/zero/1.0/) applies to the data made available in this article, unless otherwise stated. 


\section{INTRODUCTION}

Infectious diseases are caused by pathogenic microorganisms such as bacteria, viruses, parasites and fungi. This disease is frequently transmitted directly or indirectly from the patient to others around it through various media such as the air, vectors in the form of mosquitoes, etc. In Indonesia, infectious diseases which are of concern to the Ministry of Health of the Republic of Indonesia encompass Malaria, Influenza, Dengue Hemorrhagic Fever (DHF), HIV/AIDS, and tuberculosis (Badan Penelitian dan Pengembangan Kesehatan, 2013). These diseases are priorly concerned because the number of cases and impacts is quite high (Omu, 2016).

One of the infectious diseases affected by mycobacterium tuberculosis germ is Tuberculosis (TB). TB was initially discovered by Robert Koch in 1882 and is the most general infectious disease in the world due to its potential for death. TB is also included as a type of fast moving disease in which the drug for this disease is routinely administered every day (Sugiarto, \& Harijono, 2000).

The increase in the number of patients in a provided period is not proportional with the number of available medical personnel, and the drugs supply is lacking. Furthermore, the lack of ability to anticipate the occurrence of Acid Resistant Bacteria Positive Pulmonary TB in Madiun city, is due to the time, place and number of events which cannot be predicted. Moreover, there is no map of vulnerability of the region based on the time of occurrence, hence, cases of Acid Resistant Bacteria Positive Pulmonary, especially those occurring in the Madiun city continue to increase every year (Sugiarto, \& Harijono, 2000).

Forecasting possesses a significant role in the future decision making such as weather prediction, production planning, staff scheduling, and in terms of business. Thus, in this case with a lot of a field, it is required an accurate forecasting result, so that the forecasting method is significantly developed (Elfajar, et al., 2017).

One method of forecasting is the fuzzy time series method. This method has been implemented since many years ago in forecasting the number of enrollees in the Alabama University based on the existing historical data by employing simple arithmetic operations. The advantages of this method encompass the calculation process which does not require complex systems such as genetic algorithms and neural networks. Hence, this method is easy to develop (Chatfield, 2000).

Fuzzy time series is a method of data forecasting administering fuzzy principles as its basis. Forecasting by employing fuzzy time series is able to capture patterns from historical data which then is utilized to project future data (Omu, 2016). The objective of the study is to predict the number of smear acid resistant bacteria on positive pulmonary tuberculosis infection disease at Madiun city in 2021 to 2025.

\section{RESEARCH METHOD}

This study is a quantitative descriptive study employing time series analysis, which demonstrates the frequency of disease based on observation series on multiple time sequences. This study merely administered secondary data obtained from six health centers, seven hospitals \& one prison analyzed by univariate aiming to descriptively describe the identification of the research results, which is then presented in the form of tables and graphs to identify the proportion of each variable examined. It is further analyzed by employing Eviews as a measuring tool and Autoregressive Integrated 
Moving Average (ARIMA) as a projection method (Hyndman, \& Athanasopoulos, 2018).

The population and samples in this study encompassed all data on the number of acid resistant bacteria positive pulmonary TB patients in Madiun city in 2015-2019. The sampling in this study was conducted at 14 locations in Madiun city consisting of 6 health centers, 7 hospitals \& 1 prison. The data obtained was discovered from several agencies, which were Health Department of Madiun, Primary Health Center, 7 Hospitals and 1 Prison in Madiun city.

Table 1. Data on the number of Acid Resistant Bacteria Positive Pulmonary TB patients in Madiun city in 2015-2019.

\begin{tabular}{|c|c|c|c|c|c|c|}
\hline \multirow{2}{*}{ No } & \multirow{2}{*}{ Location } & \multicolumn{5}{|c|}{ Year } \\
\hline & & 2015 & 2016 & 2017 & 2018 & 2019 \\
\hline 1 & $\begin{array}{l}\text { Primary Health Center of Oro-Oro } \\
\text { Ombo }\end{array}$ & 11 & 11 & 12 & 13 & 27 \\
\hline 2 & $\begin{array}{l}\text { Primary Health Center of } \\
\text { Tawangrejo }\end{array}$ & 8 & 6 & 2 & 6 & 15 \\
\hline 3 & Primary Health Center of Banjarejo & 14 & 11 & 18 & 21 & 33 \\
\hline 4 & $\begin{array}{l}\text { Primary Health Center of } \\
\text { Demangan }\end{array}$ & 18 & 15 & 5 & 16 & 29 \\
\hline 5 & $\begin{array}{l}\text { Primary Health Center of } \\
\text { Manguharjo }\end{array}$ & 13 & 12 & 10 & 13 & 24 \\
\hline 6 & Primary Health Center of Patihan & 7 & 9 & 5 & 10 & 11 \\
\hline 7 & $\begin{array}{l}\text { dr. Soedono Central General } \\
\text { Hospital }\end{array}$ & 16 & 14 & 12 & 10 & 65 \\
\hline 8 & $\begin{array}{l}\text { Madiun City District General } \\
\text { Hospital }\end{array}$ & 5 & 11 & 10 & 15 & 156 \\
\hline 9 & TK. IV Madiun Hospital & 2 & 0 & 0 & 3 & 15 \\
\hline 10 & Manguharjo Pulmonary Hospital & 58 & 66 & 60 & 104 & 263 \\
\hline 11 & Siti Aisyah Islamic Hospital & 0 & 3 & 8 & 4 & 51 \\
\hline 12 & Santa Clara Hospital & 0 & 0 & 0 & 1 & 1 \\
\hline 13 & Prison Class I Madiun & 2 & 1 & 5 & 0 & 9 \\
\hline 14 & Griya Husada Hospital & 0 & 0 & 0 & 0 & 3 \\
\hline 15 & $\begin{array}{l}\text { Al Hasanah Mother and Child } \\
\text { Hospital }\end{array}$ & 0 & 0 & 0 & 0 & 7 \\
\hline & Total Cases & 174 & 190 & 147 & 216 & 709 \\
\hline
\end{tabular}

\section{RESULTS AND DISCUSSION}

Table 2. Acid Resistant Bacteria Positive Pulmonary TB Projection 2021-2025.

\begin{tabular}{llrrrrr} 
No & Location & \multicolumn{5}{c}{ Year } \\
\cline { 3 - 6 } & & $\mathbf{2 0 2 1}$ & $\mathbf{2 0 2 2}$ & $\mathbf{2 0 2 3}$ & $\mathbf{2 0 2 4}$ & $\mathbf{2 0 2 5}$ \\
\hline 1. & Primary Health Center of Tawangrejo & 10 & 11 & 11 & 11 & 11 \\
\hline 2. & $\begin{array}{l}\text { Primary Health Center of Oro-Oro } \\
\text { Ombo }\end{array}$ & 32 & 32 & 38 & 38 & 44 \\
\hline 3. & Primary Health Center of Demangan & 31 & 31 & 32 & 32 & 33 \\
\hline 4. & Primary Health Center of Banjarejo & 36 & 35 & 39 & 38 & 42 \\
\hline 5. & Primary Health Center of Manguharjo & 24 & 25 & 26 & 27 & 28 \\
\hline
\end{tabular}


Marsanti, A. S., \& Ardiani, H. (2021). The Prediction Number of Smear Acid Resistant Bacteria on Positive Pulmonary Tuberculosis Infection Disease at Madiun City in 2021-2025. JURNAL INFO KESEHATAN, 19(2), 162-180. https://doi.org/10.31965/infokes.Vol19/ss2.558

\begin{tabular}{llrrrrr} 
& & & & & $\mathbf{1 6 5}$ \\
\hline 6. & Primary Health Center of Patihan & 10 & 9 & 9 & 9 & 9 \\
\hline 7. & dr. Soedono Central General Hospital & 97 & 89 & 81 & 73 & 64 \\
\hline 8. & Madiun City District General Hospital & 293 & 325 & 358 & 390 & 422 \\
\hline 9. & Manguharjo Pulmonary Hospital & 289 & 307 & 324 & 341 & 358 \\
\hline 10. & Siti Aisyah Islamic Hospital & 74 & 86 & 98 & 109 & 121 \\
\hline 11. & TK. IV Madiun Hospital & 15 & 16 & 18 & 19 & 21 \\
\hline 12. & Prison Class I Madiun & 12 & 14 & 16 & 18 & 20 \\
\hline 13. & Al Hasanah Mother and Child Hospital & 8 & 10 & 11 & 13 & 14 \\
\hline 14. & Santa Clara Hospital & 2 & 2 & 2 & 2 & 3 \\
\hline & Total Cases & $\mathbf{9 3 3}$ & $\mathbf{9 9 2}$ & $\mathbf{1 0 6 3}$ & $\mathbf{1 1 2 0}$ & $\mathbf{1 1 9 0}$ \\
\hline
\end{tabular}

Table 2. Above is the result of a time series (projection) of Acid Resistant Bacteria Positive Pulmonary TB cases, if illustrated through the graph to identify the trend picture of cases to be:

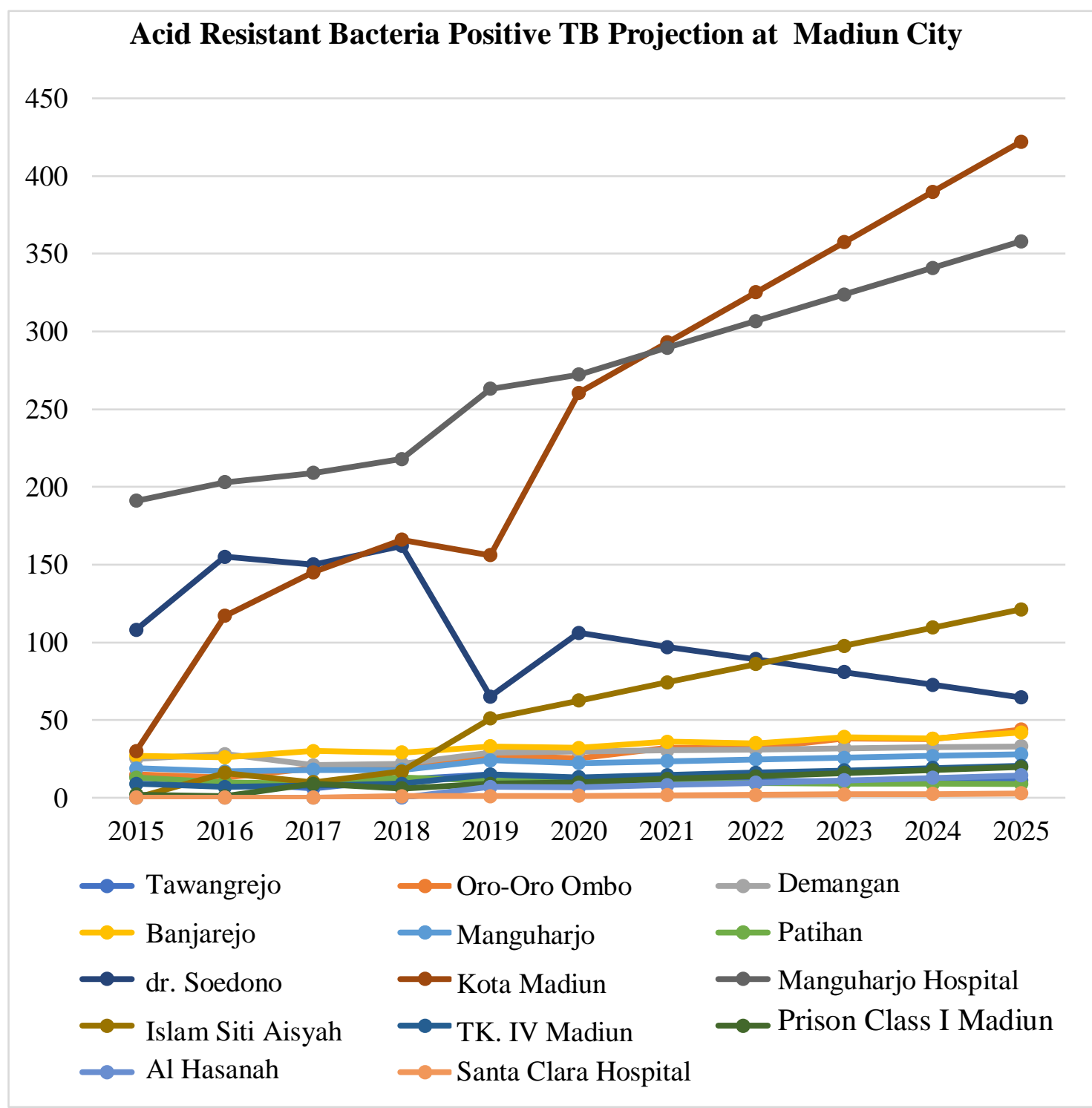

Graph 1. Cases Projection of Positive Pulmonary TB Based on Positive Pulmonary TB at Madiun City in 2015-2025. 
Based on Graph 1, it is indicated that almost all acid resistant bacteria positive pulmonary TB case projections occur every year, particularly in the projected cases of acid resistant bacteria positive pulmonary TB at Madiun city hospital, Manguharjo Pulmonary Hospital, and Siti Aisyah Islamic hospital because there were several acid resistant bacteria positive tuberculosis patients recorded in the medical records of domiciled hospitals from outside the Madiun city. Meanwhile, the number of Acid Resistant Bacteria Positive Tuberculosis in some places decreased due to the COVID-19 pandemic. Numerous patients complaining of cough were then suspected as COVID-19 sufferers directed for antigen examination and/or PCR swab test. Thus, it was not recorded as a pulmonary TB patient with Acid Resistant Bacteria Positive Pulmonary TB.

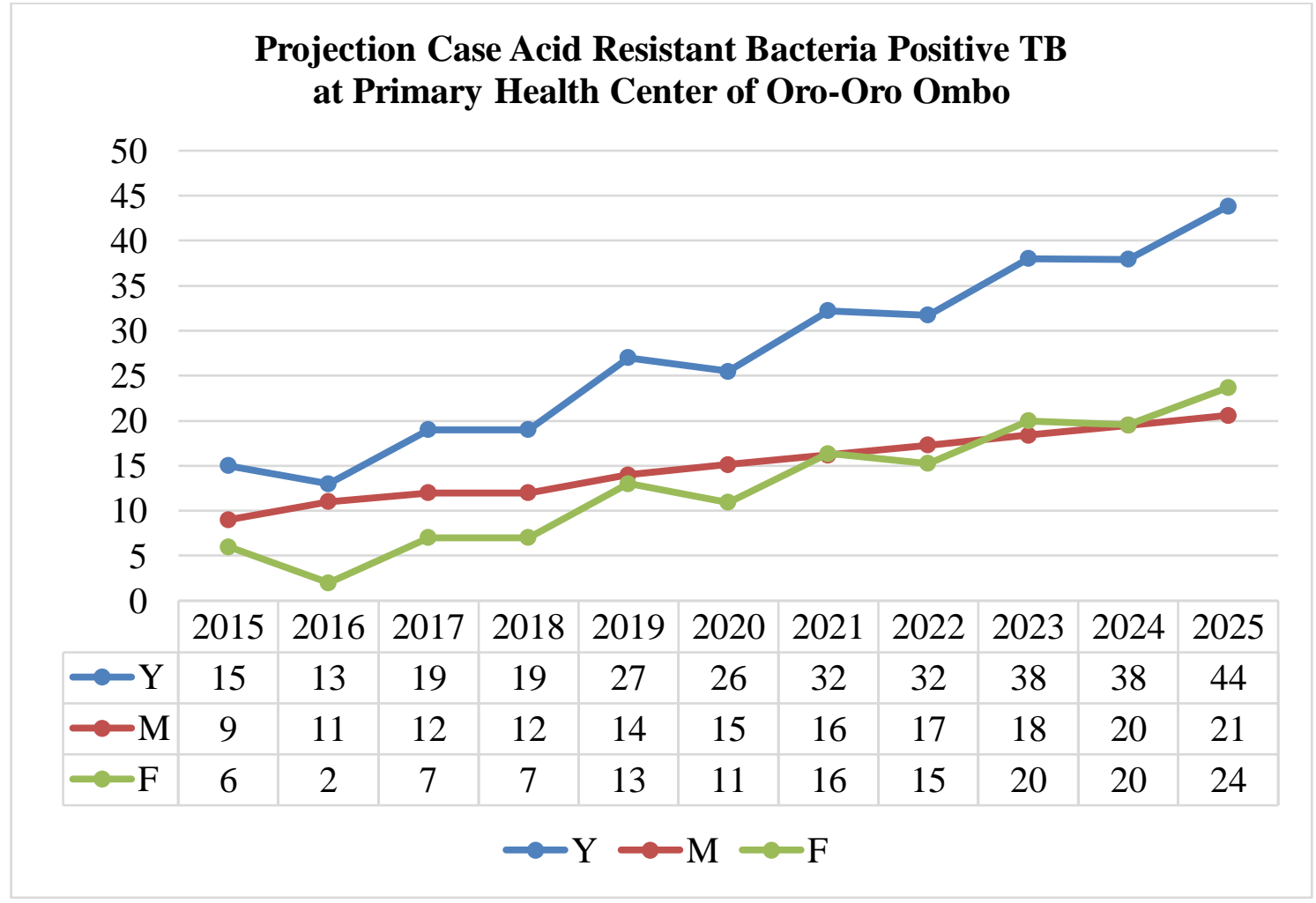

\section{Description}

Y: Total Number of Cases Per Year

M: Male

F: Female

Graph 2. Cases Projection of Positive Pulmonary TB Based on Positive Pulmonary TB at Oro-Oro Ombo Primary Health Center in 2015-2025.

Based on the graph above, the projected cases of acid resistant bacteria positive TB in the Oro-Oro Ombo primary health center presented that the number of cases is increasing every year. It is identified that acid resistant bacteria positive pulmonary TB disease is more prevalent in men, with 9 cases reported in 2015, 11 cases reported in 2016, 12 cases reported in 2017, 12 cases reported in 2018, 14 cases reported in 2019, 15 cases reported in 2020, and 16 cases reported in 2021 . There will be 17 cases in 2022, 18 cases in 2023, 20 cases in 2024, and 21 cases in 2025. 


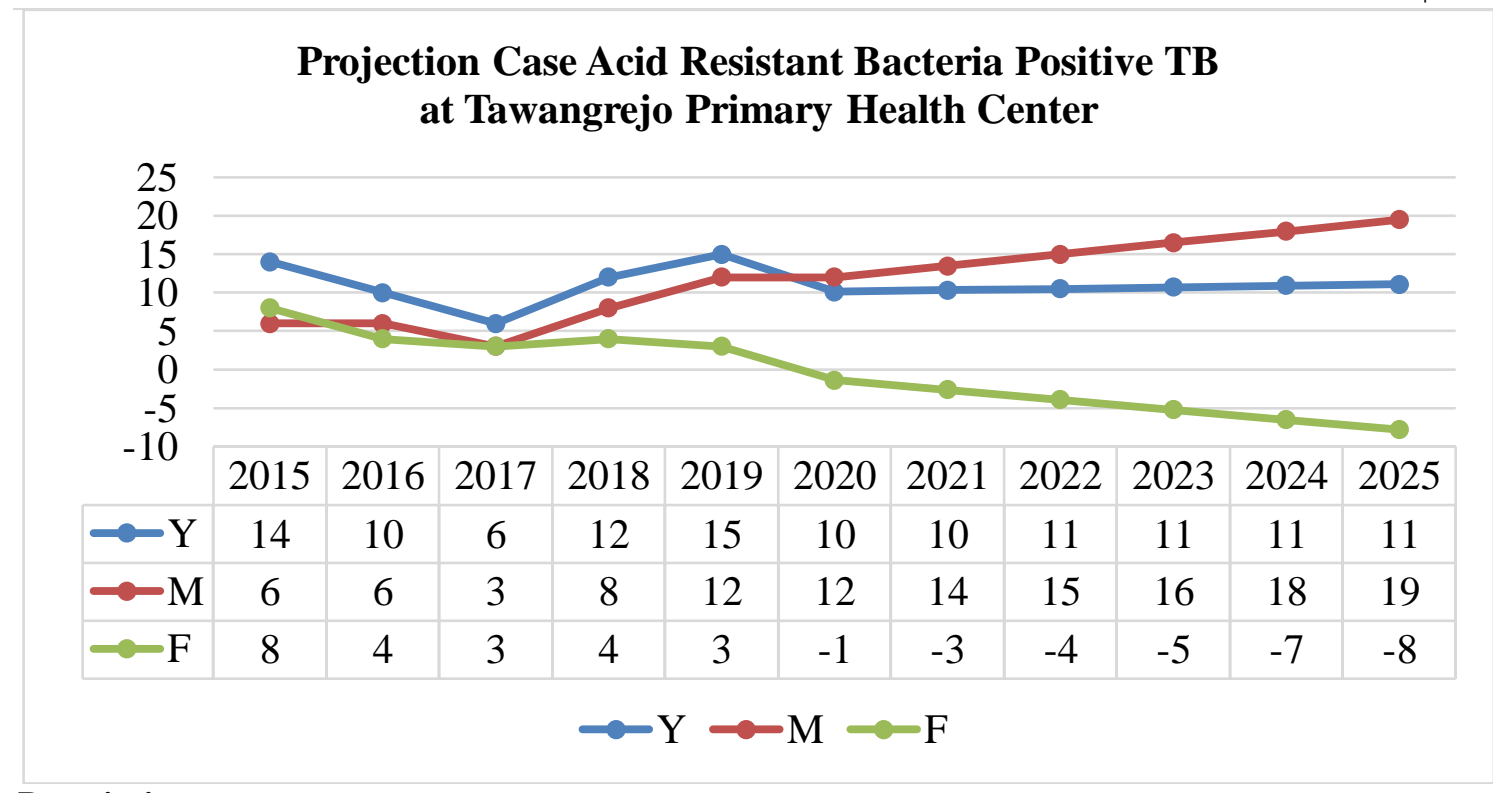

Description

Y: Total Number of Cases Per Year

M: Male

F: Female

Graph 3. Cases Projection of Positive Pulmonary TB Based on Positive Pulmonary TB at Tawangrejo Primary Health Center in 2015-2025.

Based on the graph above, the projected cases of acid resistant bacteria positive pulmonary TB in Tawangrejo primary health center revealed that the number of cases of acid resistant bacteria positive pulmonary TB illness is more prevalent in men, with 6 cases reported in 2015, 6 cases reported in 2016, 3 cases reported in 2017, 8 cases reported in 2018, and 12 cases reported in 2019. There were 12 cases in 2020, 14 cases in 2021, 15 cases in 2022, 16 instances in 2023, 18 cases in 2024, and 19 cases in 2025.

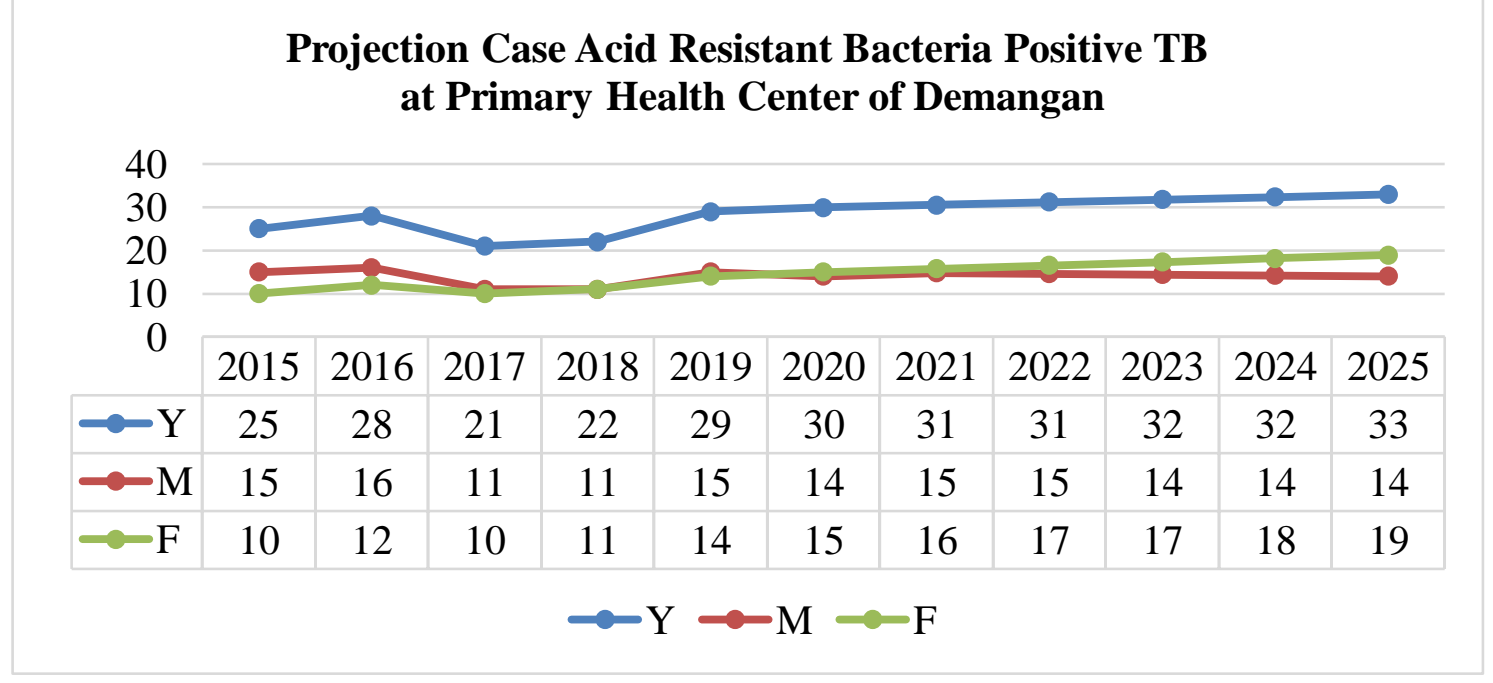

Description

Y: Total Number of Cases Per Year

M: Male

$F$ : Female 
Graph 4. Cases Projection of Positive Pulmonary TB Based on Positive Pulmonary TB at Demangan Primary Health Center in 2015-2025.

Based on the graph above, the projected cases of Acid Resistant Bacteria Positive Pulmonary TB in Demangan primary health center displayed that the number of Acid Resistant Bacteria Positive Pulmonary Tuberculosis is more common in women, with 10 cases reported in 2015, 12 cases reported in 2016, 10 cases reported in 2017, 11 cases reported in 2018, and 14 cases reported in 2019. In 2020, 15 cases were reported, followed by 16 in 2021, 17 in 2022, 17 in 2023, 18 in 2024, and 19 in 2025.

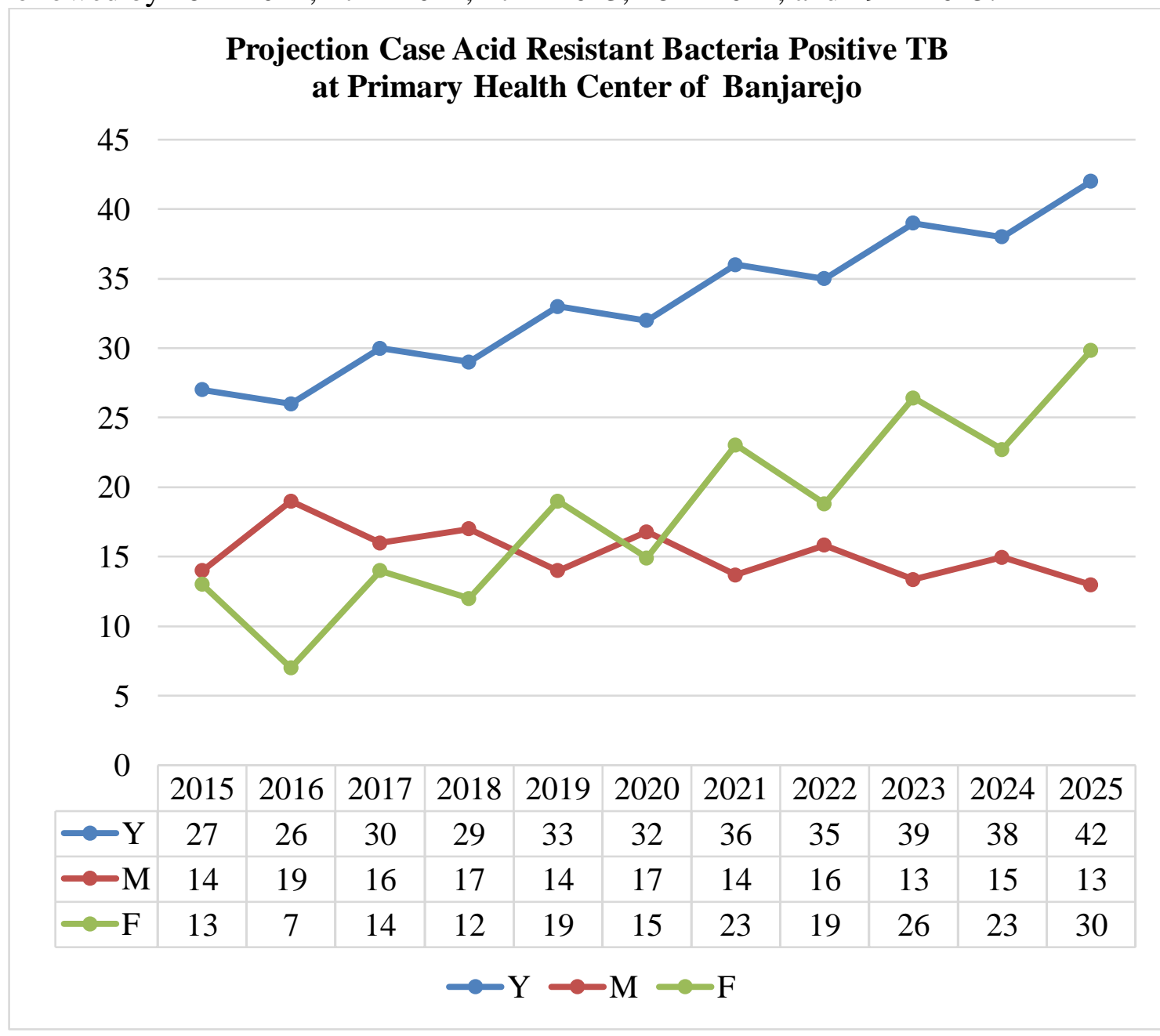

\section{Description}

Y: Total Number of Cases Per Year

M: Male

F: Female

Graph 5. Cases Projection of Positive Pulmonary TB Based on Positive Pulmonary TB at Banjarejo Primary Health Center in 2015-2025.

Based on the graph above, the projected cases of acid resistant bacteria positive pulmonary TB in Banjarejo primary health center presented that the number of cases is increasing every year. It can be observed that Acid Resistant Bacteria Positive Pulmonary TB illness is more prevalent in women, with 13 cases reported in 2015, 7 cases reported in 2016, 14 cases reported in 2017, 12 cases reported in 2018, 19 cases 
Marsanti, A. S., \& Ardiani, H. (2021). The Prediction Number of Smear Acid Resistant Bacteria on Positive Pulmonary Tuberculosis Infection Disease at Madiun City in 2021-2025. JURNAL INFO KESEHATAN, 19(2), 162-180. https://doi.org/10.31965/infokes.Vol19/ss2.558

169

reported in 2019, 15 cases reported in 2020, and 23 cases reported in 2021. There were 19 cases in 2022, 26 cases in 2023, 23 cases in 2024, and up to 30 cases in 2025.

\section{Projection Case Acid Resistant Bacteria Positive TB at Primary Health Center of Manguharjo}

\section{5}

30

25

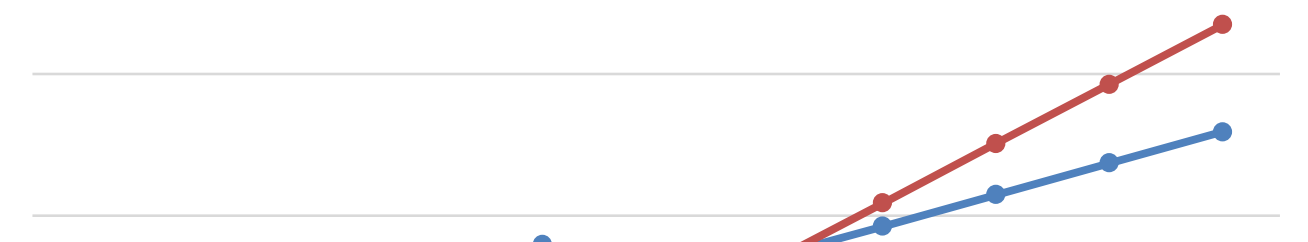

20

15

10

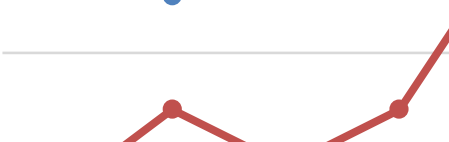

5

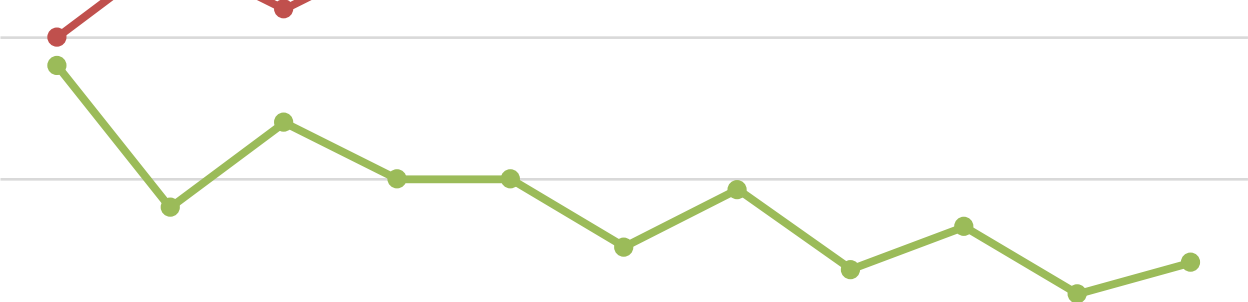

0

\begin{tabular}{|l|l|l|l|l|l|l|l|l|l|l|}
\hline 2015 & 2016 & 2017 & 2018 & 2019 & 2020 & 2021 & 2022 & 2023 & 2024 & 2025 \\
\hline
\end{tabular}

\begin{tabular}{|c|c|c|c|c|c|c|c|c|c|c|c|}
\hline$\multimap \mathrm{Y}$ & 19 & 17 & 18 & 18 & 24 & 22 & 24 & 25 & 26 & 27 & 28 \\
\hline$\multimap-\mathrm{M}$ & 10 & 13 & 11 & 13 & 19 & 21 & 23 & 25 & 28 & 30 & 32 \\
\hline$\multimap-\mathrm{F}$ & 9 & 4 & 7 & 5 & 5 & 3 & 5 & 2 & 3 & 1 & 2 \\
\hline
\end{tabular}

$\rightarrow \mathrm{Y} \rightarrow \mathrm{M} \rightarrow \mathrm{F}$

\section{Description}

Y: Total Number of Cases Per Year

M: Male

F: Female

Graph 6. Cases Projection of Positive Pulmonary TB Based on Positive Pulmonary TB at Manguharjo Primary Health Center in 2015-2025.

Based on the graph above, the projected cases of Acid Resistant Bacteria Positive Pulmonary TB at Manguharjo primary health center presented that acid resistant bacteria positive pulmonary TB disease is more prevalent in the male sex, with 10 instances reported in 2015, 13 cases reported in 2016, 11 cases reported in 2017, 13 cases reported in 2018, and 19 cases reported in 2019. There will be 21 cases in 2020, 23 cases in 2021, 25 cases in 2022, 28 cases in 2023, 30 cases in 2024, and 32 cases in 2025. 


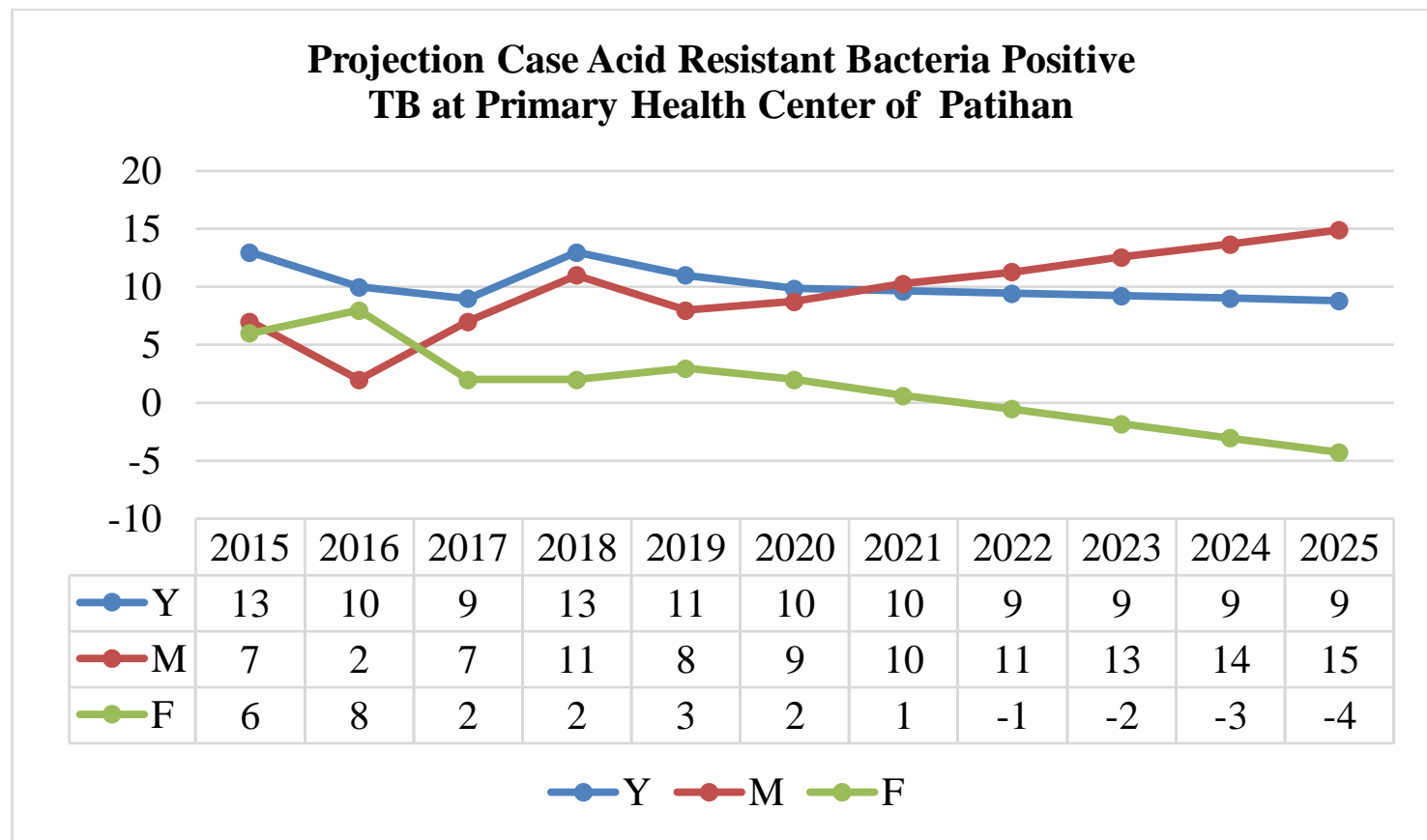

Description

Y: Total Number of Cases Per Year

M: Male

F: Female

Graph 7. Cases Projection of Positive Pulmonary TB Based on Positive Pulmonary TB at Patihan Primary Health Center in 2015-2025.

Based on the graph above the projected cases of Acid Resistant Bacteria Positive Pulmonary TB in Patihan Primary Health Center displayed that Bacteria Positive Pulmonary TB disease is more dominant in the male sex in 2015, there were 7 cases of Acid Resistant Bacteria Positive Pulmonary TB disease, in 2016 there were 2 cases, in 2017 there were 7 cases, in 2018 there were 11 cases, in 2019 there were 8 cases, in 2020 there were 9 cases, in 2021 there were 10 cases, in 2022 there were 11 cases, in 2023 there were 13 cases, in 2024 there were 14 cases, and in 2025 there were 15 cases.

\section{Projection Case Acid Resistant Bacteria Positive TB at dr. Soedono Central General Hospital}

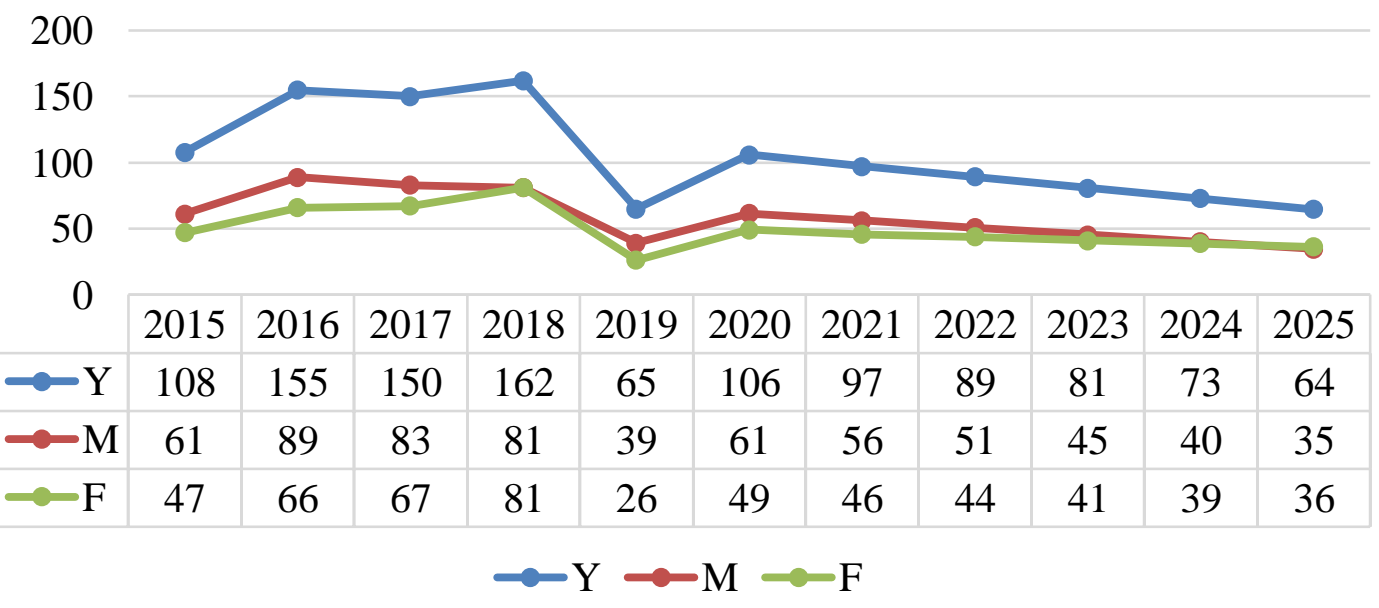




\section{Description}

Y: Total Number of Cases Per Year

M: Male

F: Female

Graph 8. Cases Projection of Positive Pulmonary TB Based on Positive Pulmonary TB at dr. Soedono hospital in 2015-2025.

Based on the graph above the projected case of Acid Resistant Bacteria Positive Pulmonary TB in dr. Soedono central general hospital revealed that the male sex has a higher prevalence of acid resistant bacteria positive pulmonary TB illness, with 61 cases in 2015,89 cases in 2016, 83 cases in 2017, 81 cases in 2018, 39 cases in 2019, 61 cases in 2020, and 56 cases in 2021. There were 51 instances in 2022, 45 cases in 2023, 40 cases in 2024, and 35 cases in 2025.

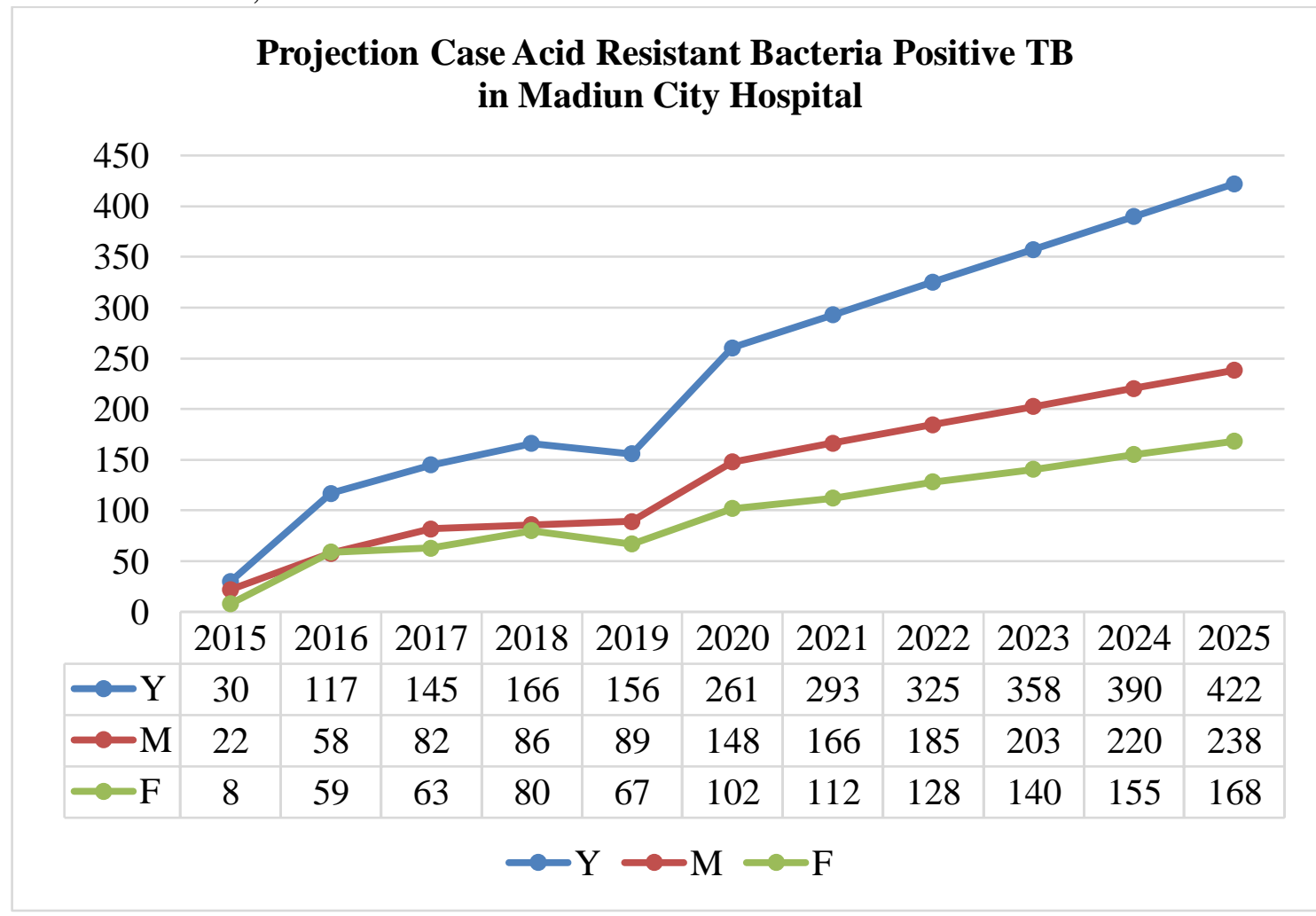

\section{Description}

Y: Total Number of Cases Per Year

M: Male

F: Female

Graph 9. Cases Projection of Positive Pulmonary TB Based on Positive Pulmonary TB at Madiun City Hospital in 2015-2025.

Based on the graph above, the projected cases of acid resistant bacteria positive pulmonary TB in Madiun city hospital presented that acid resistant bacteria positive pulmonary TB illness is more prevalent in males, with 22 cases reported in 2015, 58 cases reported in 2016, 82 cases reported in 2017, 86 cases reported in 2018, and 89 cases reported in 2019. There were 148 cases in 2020, 166 cases in 2021,185 cases in 2022, as much as 203 cases in 2023, 220 cases in 2024, and 238 cases in 2025. 


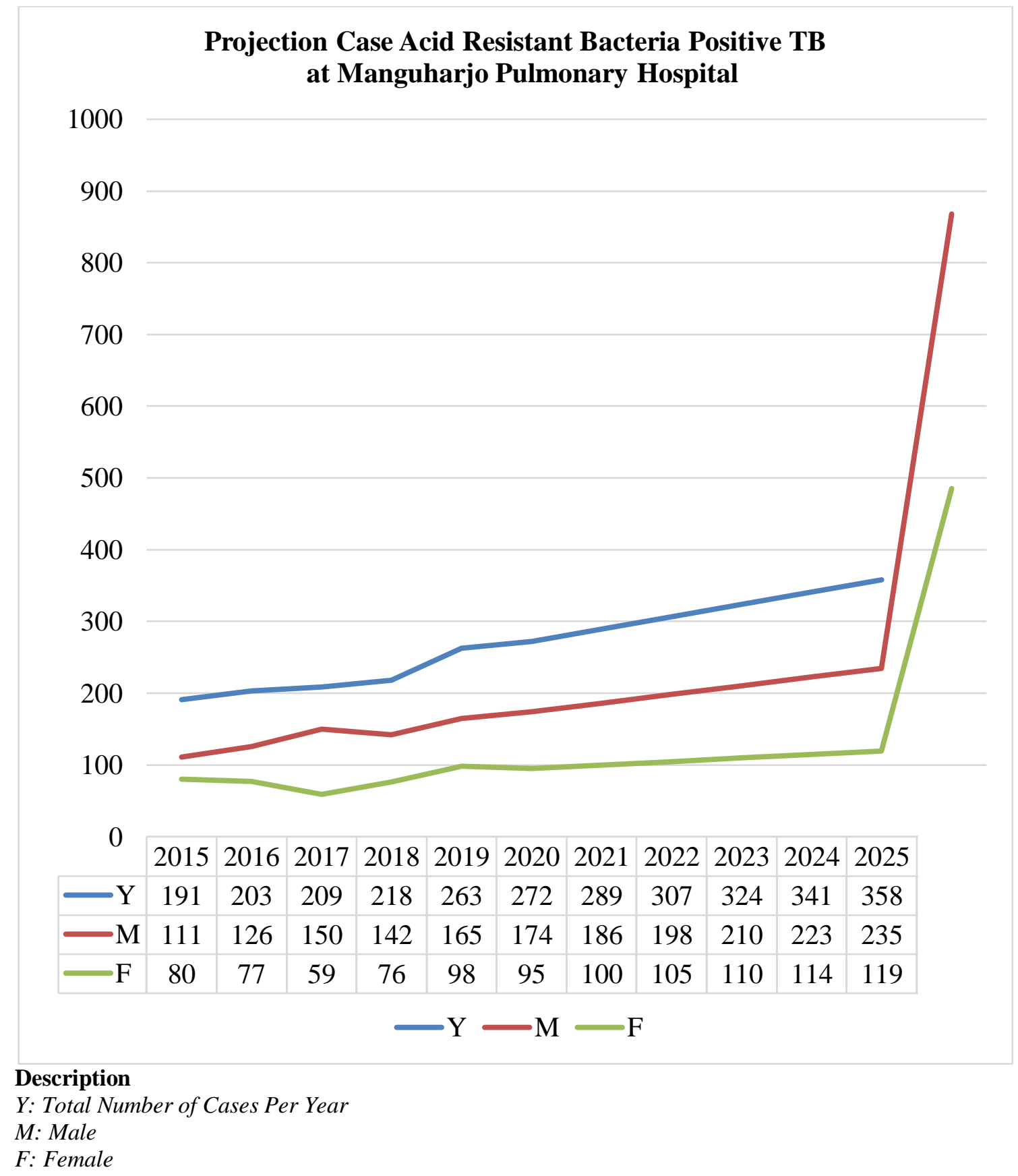

Graph 10. Cases Projection of Positive Pulmonary TB Based on Positive Pulmonary TB at Manguharjo Pulmonary Hospital in 2015-2025.

Based on the graph above, the projected cases of acid resistant bacteria positive pulmonary TB in Manguharjo pulmonary hospital revealed that the number of cases increases every year. It can be identified that the male sex has a higher prevalence of Acid Resistant Bacteria Positive Pulmonary TB illness, with 111 cases in 2015, 126 cases in 2016, 150 cases in 2017, 142 cases in 2018, 165 cases in 2019, 174 cases in 2020, and 186 cases in 2021. There were 198 incidences in 2022, 210 cases in 2023, 223 cases in 2024, and 235 cases in 2025. 


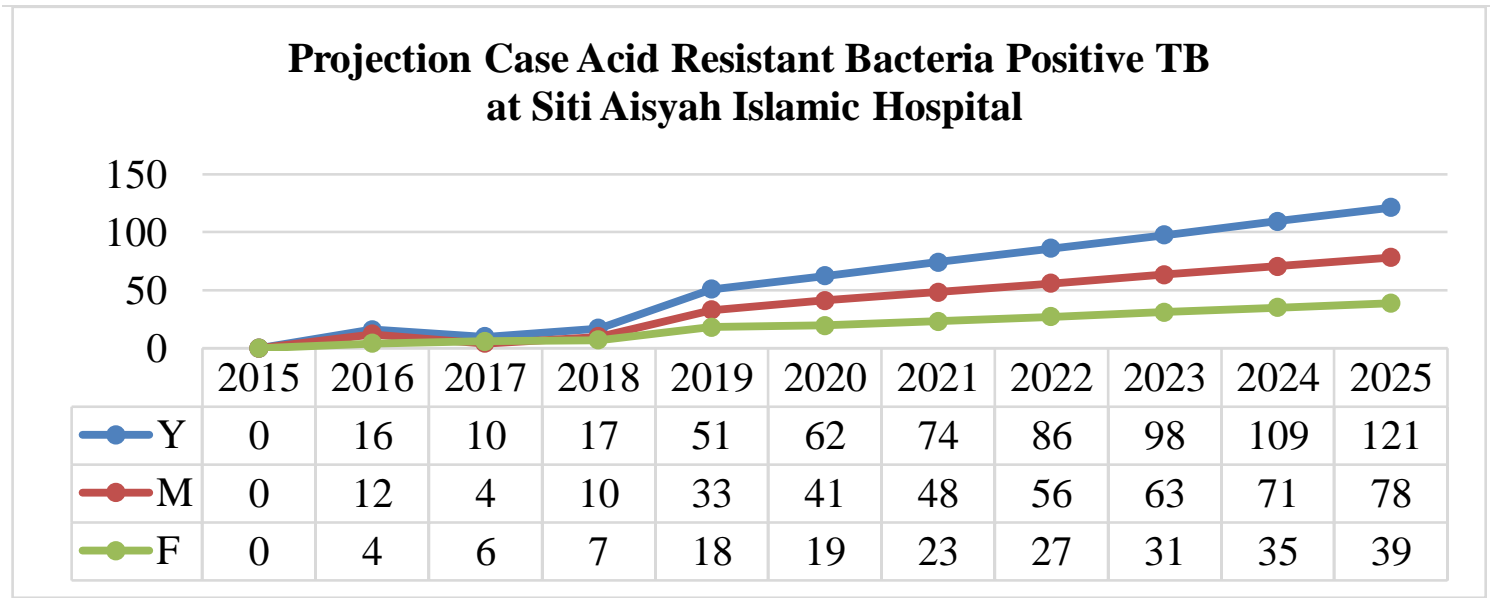

\section{Description}

Y: Total Number of Cases Per Year

M: Male

F: Female

Graph 11. Cases Projection of Positive Pulmonary TB Based on Positive Pulmonary TB at Siti Aisyah Islamic Hospital in 2015-2025.

Based on the chart above, the projected cases of acid resistant bacteria positive pulmonary TB in Siti Aisyah Islamic hospital presented that the number of cases increases every year. It can be indicated that Acid Resistant Bacteria Positive Pulmonary TB illness is more prevalent in men, with 12 cases reported in 2016, 4 cases reported in 2017, 10 cases reported in 2018, 33 cases reported in 2019, 41 cases reported in 2020, 48 cases reported in 2021, and 56 cases reported in 2022. There will be 63 instances in 2023, 71 cases in 2024, and 78 cases in 2025.

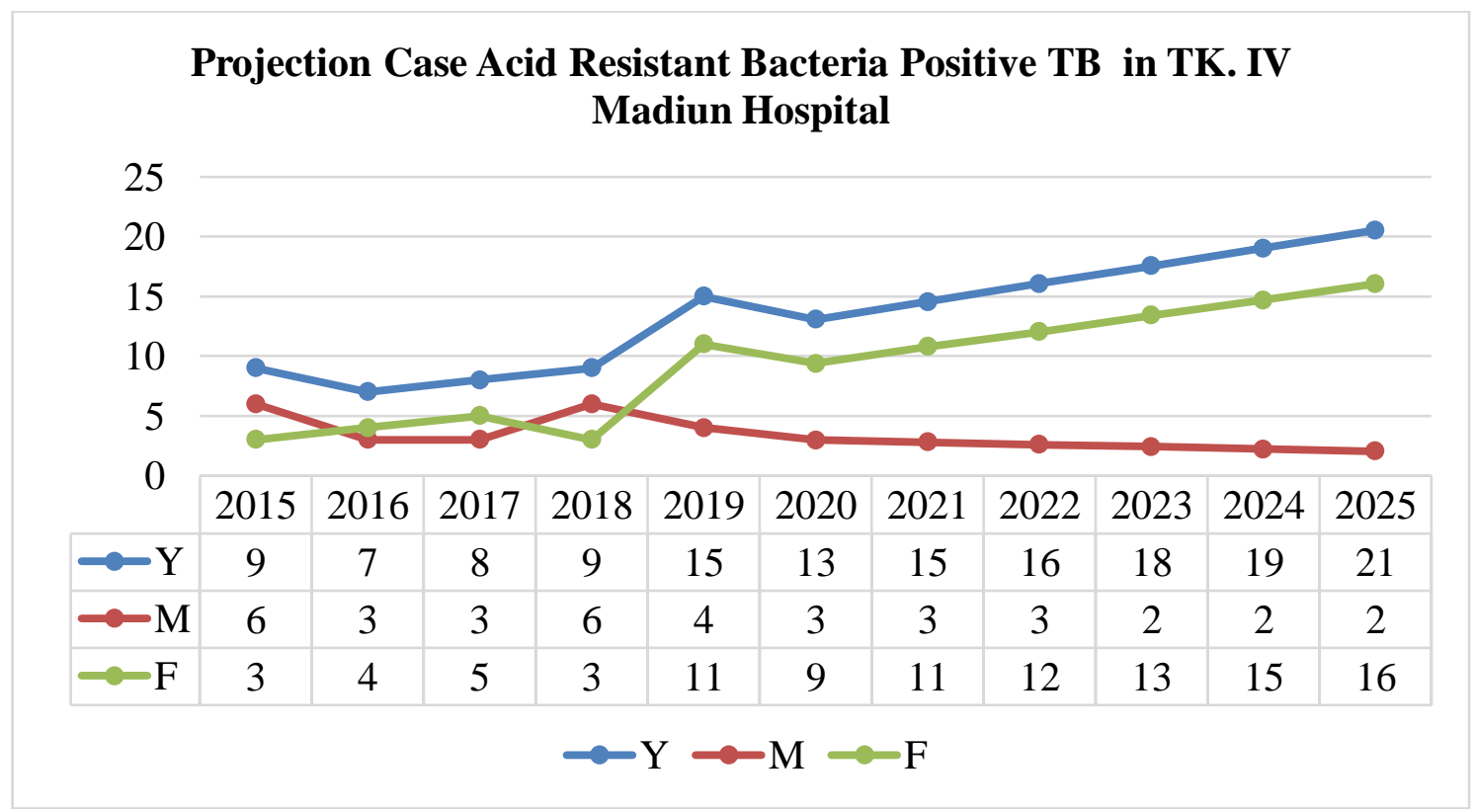

\section{Description}

Y: Total Number of Cases Per Year

M: Male

F: Female 
Graph 12. Cases Projection of Positive Pulmonary TB Based on Positive Pulmonary TB at TK. IV Madiun Hospital in 2015-2025.

Based on the graph above, the projected case of acid resistant bacteria positive pulmonary TB in TK IV Madiun hospital presented that Acid Resistant Bacteria Positive Pulmonary TB disease was more dominant in the female sex in 2015, there were six cases of Acid Resistant Bacteria Positive Pulmonary TB illness, three cases in 2016 , three cases in 2017, six cases in 2018, six cases in 2019, four cases in 2020, and eleven cases in 2021. Twelve cases were reported in 2022, thirteen in 2023, fifteen in 2024, and sixteen in 2025 .

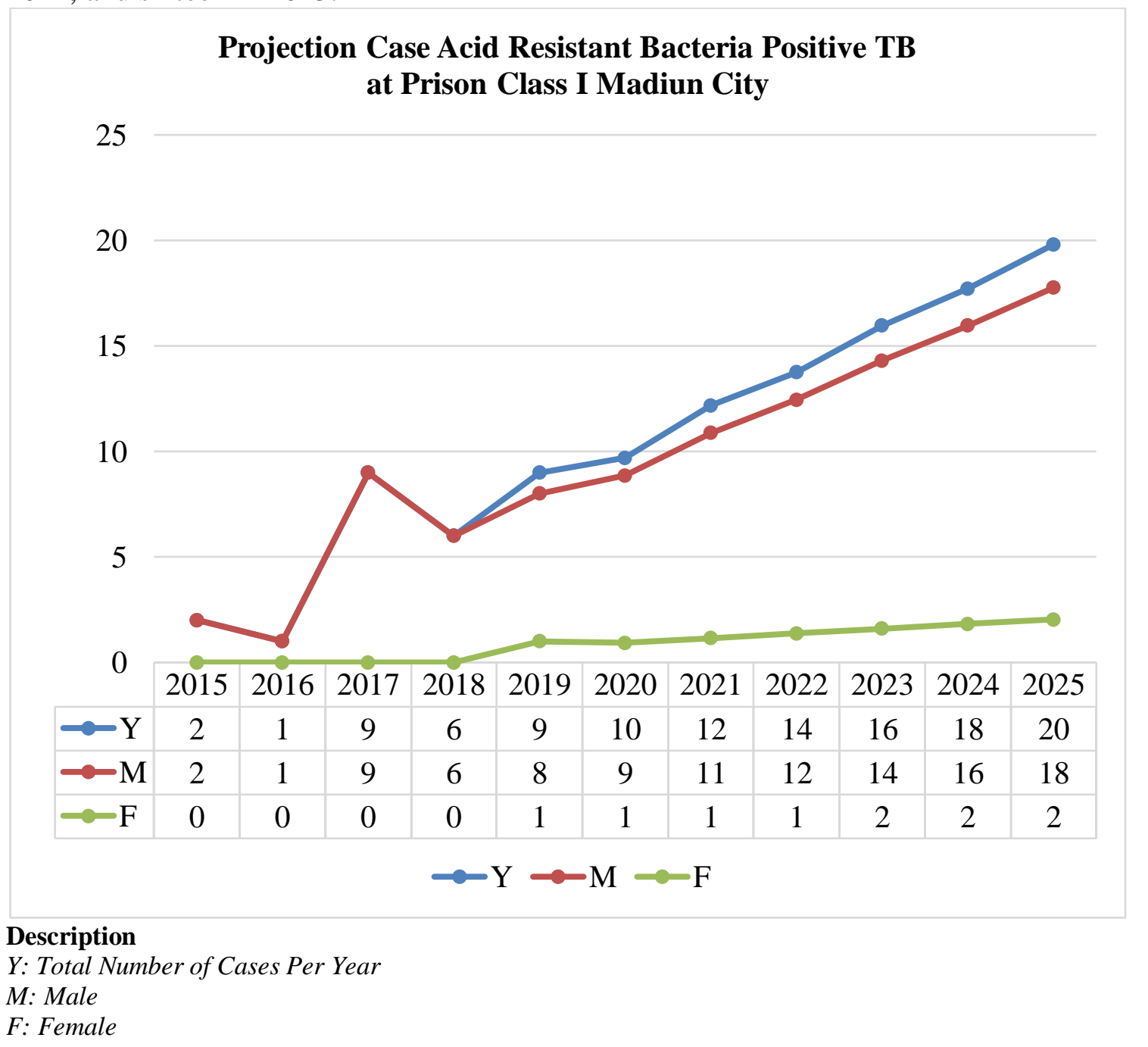

Graph 13. Cases Projection of Positive Pulmonary TB Based on Positive Pulmonary TB at Prison Class I Madiun City in 2015-2025.

Based on the graph above, the projection of acid resistant bacteria positive pulmonary TB cases in the Prison Class I of Madiun city presented that the number of cases increases every year. It can be evident that Acid Resistant Bacteria Positive Pulmonary TB illness is more prevalent in men, with 2 cases reported in 2015, 1 case reported in 2016, 9 cases reported in 2017, 6 cases reported in 2018, 8 cases reported in 
Marsanti, A. S., \& Ardiani, H. (2021). The Prediction Number of Smear Acid Resistant Bacteria on Positive Pulmonary Tuberculosis Infection Disease at Madiun City in 2021-2025. JURNAL INFO KESEHATAN, 19(2), 162-180. https://doi.org/10.31965/infokes.Vol19/ss2.558

175

2019, 9 cases reported in 2020, and 11 cases reported in 2021. There were 12 cases in 2022, 14 cases in 2023, 16 cases in 2024, and 18 cases in 2025.

\section{Projection Case Acid Resistant Bacteria Positive TB at Al Hasanah Mother and Child Hospital}

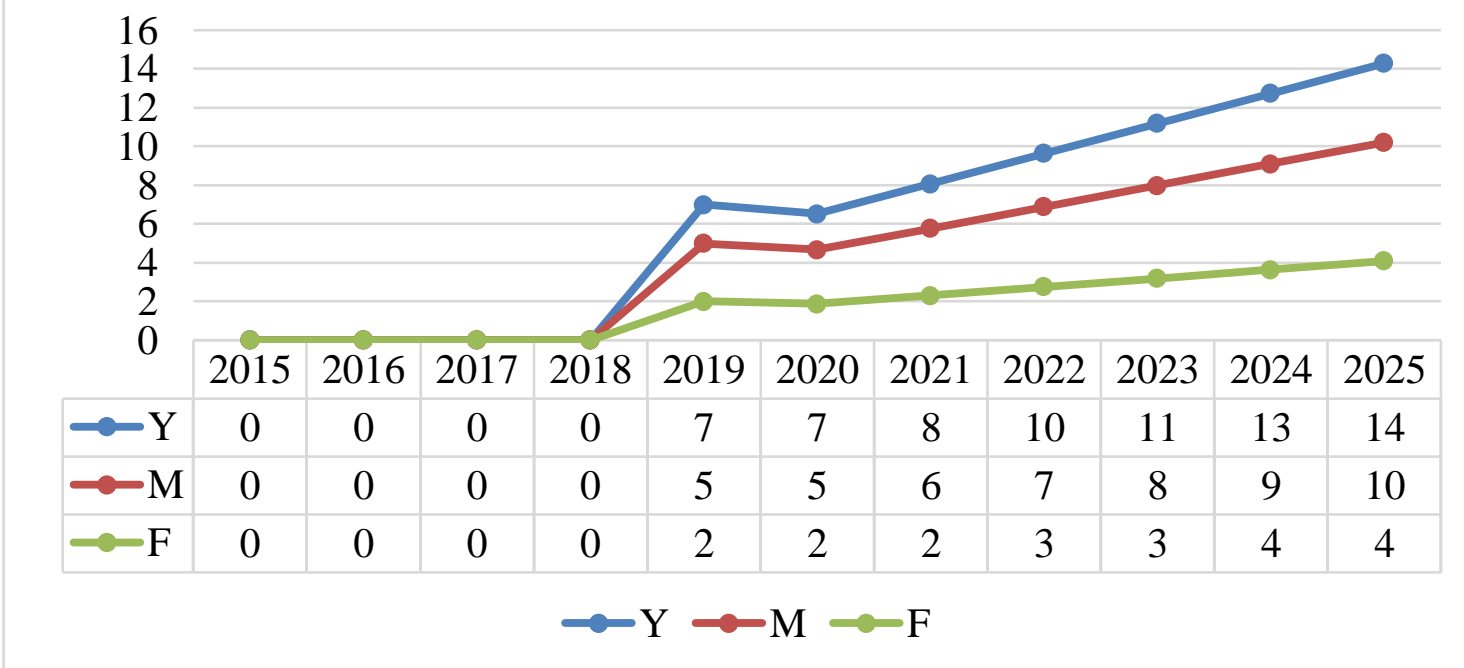

Description

$Y$ : Total Number of Cases Per Year

$M:$ Male

$F$ : Female

Graph 14. Cases Projection of Positive Pulmonary TB Based on Positive Pulmonary TB at Al Hasanah Mother and Child Hospital in 2015-2025.

Based on the graph above, the projected cases of acid resistant bacteria positive pulmonary TB in Al Hasanah mother and child hospital revealed that the number of cases increases every year. It can be observed that Acid Resistant Bacteria Positive Pulmonary TB illness is more prevalent in men, with 5 cases reported in 2019, 5 cases reported in 2020, 6 cases reported in 2021, 7 cases reported in 2022, 8 cases reported in 2023, 9 cases reported in 2024, and 10 cases reported in 2025.

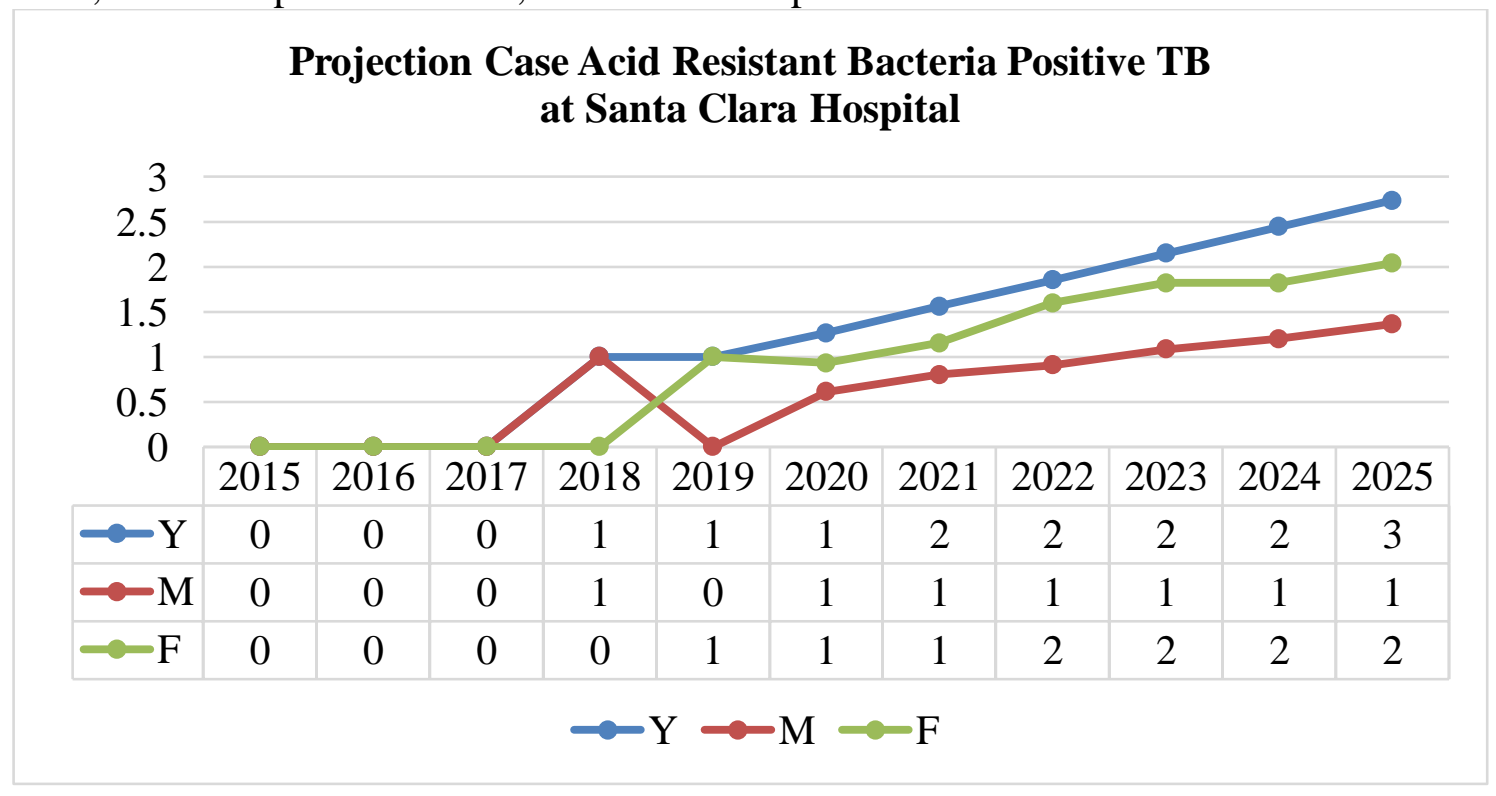




\author{
Description \\ $Y$ : Total Number of Cases Per Year \\ $M:$ Male \\ $F$ : Female
}

Graph 15. Cases Projection of Positive Pulmonary TB Based on Positive Pulmonary TB at Santa Clara Hospital in 2015-2025.

Based on the graph above, the projected cases of Acid Resistant Bacteria Positive Pulmonary TB in Santa Clara hospital presented that Acid Resistant Bacteria Positive Pulmonary TB Disease is more prevalent in women, with 1 case reported in 2019, 1 case reported in 2020, 1 case reported in 2021, 2 cases reported in 2022, and 2 cases reported in 2023. There will be two cases in 2024, and two cases in 2025.

Prediction of acid resistant bacteria positive pulmonary TB Incidence by Gender. Based on the results of research, it is revealed the projected case data of acid resistant bacteria positive pulmonary TB in the Madiun city, which is the male sex, more case data compared to the results of projected cases of female patients. It is in accordance with the research result (Susanto, et al., 2016) displaying that cases of Acid Resistant Bacteria Positive Pulmonary TB based on gender in Kendari city in 2016-2014 frequently increases every year, in which in 2014, there were 247 cases for people with acid resistant bacteria positive pulmonary TB in male, while in female by 163 cases.

In the prediction period, in 2016-2020, it is predicted that acid resistant bacteria positive pulmonary TB cases continue to increase, in 2020, the highest number of cases will be in the male sex with a total of 602 cases. Similar results were also revealed by previous researchers (Hastuti, et al., 2016) that the results of forecasting presented the number of pulmonary TB morbidity rates based on gender from year to year which is increase in which the highest number of cases was male sex.

According to (Dotulong, et al., 2015), the number of Pulmonary TB incidences occurring in men because men prefer high mobility than women. Thus, the possibility to be exposed is greater. Moreover, the habits such as smoking and consuming alcohol may lower the immune system, thus, it is natural that smokers and alcohol drinkers are frequently referred to as agents of pulmonary TB disease. Men possess a heavier workload, less rest, and a less healthy lifestyle.

The results of the study (Andayani, 2020) possess a prediction of pulmonary TB incidence in accordance with the sex of the most sufferers that is the male sex estimated to decrease the pulmonary TB incidences in early 2017 , then increase the pulmonary TB incidence in the middle of the year after, while at the end of 2020, there is a decrease in the pulmonary TB cases, but still in small numbers than in the previous year. Meanwhile, the female sex possesses the smallest predicted incidence of pulmonary TB. In 2018 prediction, the highest number of cases was in the male sex with 222 cases, and in the female sex of 141 cases (Korua, et al., 2014).

It is corroborated by research conducted by (Mahfuzhah, 2014) in Pontianak city which revealed that statically, there is a relationship between male sex and people with pulmonary tuberculosis. Results from a (Atik, 2013) study uncovered that cases of acid resistant bacteria positive pulmonary TB disease by gender, discovered that men are 1.5 times more likely than in women.

The results of this study are in accordance with research conducted by (Mangngi, 2019) which unveiled that there is a meaningful relationship between sex and the incidence of pulmonary TB in Naibonat, East Kupang, Kupang Regency, in which the 
male sex owns 2.7 times more risk of lung TB disease than the female sex (Samsugito, 2018). It is because men possess higher mobility than women and also other bad habits such as smoking and consuming alcohol causing the immune system to decrease so that it makes it easier for men infected with pulmonary TB (Pangaribuan, et al., 2020).

Research in India also discovered that smokers possess a higher risk of being infected with pulmonary TB disease compared to (Nurjana, 2015). Furthermore, research from (Nurhana, et al., 2010) revealed that there is a meaningful relationship between sex and the incidence of pulmonary TB. This study states that men are more likely to suffer from pulmonary TB than women.

The results of this study as revealed by (Naga, 2012) unveiled that in men, pulmonary TB disease is higher than in women due to the habit of men who frequently smoke and consume alcoholic beverages that lower the body's defense system. Thus, it is natural that smokers and alcohol drinkers are commonly referred to as agents of pulmonary TB disease.

Prediction of acid resistant bacteria positive pulmonary TB incidence according to acid resistant bacteria positive pulmonary TB case data. Based on the results of research demonstrated the results of data analysis time series (projection) cases of acid resistant bacteria positive pulmonary TB experiencing an increase. It is also in accordance with research (Susanto, et al., 2016) presenting that cases of acid resistant bacteria positive pulmonary TB in the period 2010-2014 tend to increase with the cases number of 255 , $280,314,333$, and 410 cases, respectively. In the prediction period, in 2016-2020, it is predicted that cases of acid resistant bacteria positive pulmonary TB continue to increase with cases of 553, 646, 752, 871, and 1003 cases, respectively. The results are in accordance with previous research (Hastuti, et al., 2016) that the results of forecasting pulmonary TB morbidity (forecasting) at the predicted period of 2013-2015 experienced an increase in cases of Acid Resistant Bacteria Positive Pulmonary TB.

Please note that the highest prediction results of acid resistant bacteria positive pulmonary TB patients are assumed if the facilities and infrastructure, existing health facilities are still the same as the state of health facilities in the period before the prediction, hence, it affects the high and low number of cases of prediction results.

Predictions of the rise or fall of Pulmonary TB case data can also be influenced by the COVID-19 pandemic. Many patients complaining of cough pain is then suspected as COVID-19 sufferers directed to have an antigen examination and/or PCR swab test. Thus, it is not followed up for specimen examination of positive Acid Resistant Bacteria sputum (tuberculosis).

Other factors affecting the incidence of acid resistant bacteria positive pulmonary TB are environmental and socioeconomic factors. Soil floor types, for instance, can indicate very basic dwelling conditions that do not match the standards, are difficult to clean, dusty, and tend to be wet and dark. This is a perfect environment for bacteria and viruses to thrive and survive for prolonged periods of time. People who enter the residence with acid resistant bacteria positive pulmonary $\mathrm{TB}$ are more easily disseminated to other inhabitants (Crofton, et al., 2002). House contact is a very serious threat to other family members to suffer from tuberculosis because it is a source of intensive transmission which is around the daily lives of other family members. Close contact with people with acid resistant bacteria positive pulmonary TB is at maximum risk for infection. Delays in providing treatment increase the possibility of transmission risk (Apriani, 2001). 
Socio-economic factors, such as income per capita, illustrate a person's economic ability which broadly influences other aspects of life, such as healthy behavior, education, housing, and others. From the health aspect, families with high-per-capita income can meet the needs of their family members, such as nutritional needs, healthy housing and health care, in reducing the risk of TB disease (Jaya, \& Mediarti., 2017). The relationship between per capita income and tuberculosis may occur reciprocally. Under certain conditions, pulmonary tuberculosis attacking family members who are the backbone of the family economy can directly influence the family's per capita income, due to the lack of productive working days (Aditama, 2005).

Based on the results of (Sarce dan Suarni, 2016), it is explained that during the last 3 years from 2013-2015, there was an increase in acid resistant bacteria positive pulmonary TB cases every year in almost all areas of Kendari city Sub district. The results of the study (Andayani \& Astuti, 2017) presented that the distribution of pulmonary TB patients in Ponorogo Regency in 2010-2015 frequently increase every year. At the time of prediction, which is in 2016-2020, it is predicted that pulmonary TB cases keep increasing.

\section{CONCLUSION}

Based on the results of this study, it can be identified that the time series (projection) data of acid resistant bacteria positive pulmonary tb patients in madiun city in 2021-2025 keep increasing every year in which the most cases are dominated by male community groups. There are several factors influencing the increase or decrease in the incidence of positive smear pulmonary TB. Thus, it is necessary to analyze the risk factors causing the incidence of positive smear pulmonary TB based on the health service work area or community characteristics and conduct preventive and promotive activities to reduce the incidences of positive smear pulmonary TB particularly in the male sex group.

\section{REFERENCES}

Aditama, T. Y. (2005). Tuberkulosis dan Kemiskinan. Majalah Kedokteran Indonesia, 55(2), 49-50.

Andayani, S. (2020). Prediksi Kejadian Penyakit Tuberkulosis Paru Berdasarkan Jenis Kelamin. Jurnal Keperawatan Muhammadiyah Bengkulu, 8(2), 135-140. doi: https://doi.org/10.36085/jkmu.v8i2.1063.

Andayani, S., \& Astuti, Y. (2017). Prediksi Kejadian Penyakit Tuberkolosis Paru Berdasarkan Usia di Kabupaten Ponorogo Tahun 2016-2020. Indonesian Journal for Health Sciences, 1(2), 29-33. doi: http://dx.doi.org/10.24269/ijhs.v1i2.482

Apriani, W. (2001). Faktor-faktor Yang Berhubungan Dengan Kejadian TB Paru di Kabupaten Donggala Provinsi Sulawesi Tengah Tahun 2000. Jakarta: Program Studi Epidemiologi, Universitas Indonesia.

Atik, P. (2013). Faktor-faktor Yang Berhubungan Dengan Kejadian Tuberkulosis Paru Pada Usia Dewasa (Studi Kasus Di Balai Pencegahan dan Pengobatan Penyakit Paru). Jurnal Ilmiah Kesehatan, 4, 25-32.

Badan Penelitian dan Pengembangan Kesehatan. (2013). Penyakit Menular NonNeglected: Kajian dan Program Penelitian. Jakarta: Badan Penelitian dan Pengembangan Kesehatan: Kementerian Kesehatan Republik Indonesia.

Chatfield, C. (2000). Time-series forecasting. CRC press.

Crofton, J., Horne, N., Miller, F. (2002). Tuberkulosis Klinis (2nd ed), diterjemahkan 
Marsanti, A. S., \& Ardiani, H. (2021). The Prediction Number of Smear Acid Resistant Bacteria on Positive Pulmonary Tuberculosis Infection Disease at Madiun City in 2021-2025. JURNAL INFO KESEHATAN, 19(2), 162-180. https://doi.org/10.31965/infokes.Vol19/ss2.558

| 179

oleh dr. Muherman Harun. Jakarta: Widya Medika.

Dotulong, J. F. J, Sapulete, M. R., \& Kandou, G. D. (2015). Hubungan faktor risiko umur, jenis kelamin dan kepadatan hunian dengan kejadian penyakit TB Paru di Desa Wori Kecamatan Wori. Jurnal Kedokteran Komunitas dan Tropik, 3(2), 5765.

Elfajar, A., Setiawan, B., \& Dewi, C. (2017). Peramalan Jumlah Kunjungan Wisatawan Kota Batu Menggunakan Metode Time Invariant Fuzzy Time Series. Jurnal Pengembangan Teknologi Informasi Dan Ilmu Komputer, 1(2), 85-94.

Jaya, H., \& Mediarti, D. (2017). Faktor-Faktor yang Berhubungan dengan Tuberkulosis Paru Relaps Pada Pasien di Rumah Sakit Khusus Paru Provinsi Sumatera Selatan Tahun 2015-2016. JPP (Jurnal Kesehatan Poltekkes Palembang), 12(1), 71-82. Retrieved from https://jurnal.poltekkespalembang.ac.id/index.php/JPP/article/view/19

Hastuti, T., Ahmad, L. O. A. I., \& Ibrahim, K. (2016). Analisis Spasial, Korelasi dan Tren Kasus TB Paru BTA Positif Menggunakan Web Sistem Informasi Geografis Di Kota Kendari Tahun 2013-2015. Jurnal Ilmiah Mahasiswa Kesehatan Masyarakat Unsyiah, 1(3), 18-29.

Hyndman, R. J., \& Athanasopoulos, G. (2018). Forecasting: principles and practice, 2nd edition. Melbourne, Australia: Otexts. Available on https://otexts.com/fpp2/

Korua, E. S., Kapantow, N. H., \& Kawatu, P. A. T. (2014). Hubungan Antara Umur, Jenis Kelamin, dan Kepadatan Hunian Dengan Kejadian TB Paru Pada Pasien Rawat Jalan Di Rumah Sakit Umum Daerah Noongan. Jurnal Kesehatan Masyarakat Universitas Sam Ratulangi, 21-29.

Mangngi, M. P. (2019). Faktor Risiko Umur, Jenis Kelamin, dan Kepadatan Hunian Terhadap Kejadian TB Paru Di Puskesmas Naibonat Tahun 2018. Diploma thesis. Program Studi Analis Kesehatan, Politeknik Kesehatan Kemenkes Kupang.

Mahfuzhah, I. (2014). Gambaran faktor risiko penderita TB paru berdasarkan status gizi dan pendidikan di RSUD Dokter Soedarso. Jurnal Mahasiswa PSPD FK Universitas Tanjungpura, 1(1), 1-13.

Naga, S, S. (2012). Buku Panduan Lengkap Ilmu Penyakit Dalam. Yogyakarta: DIVA Press.

Nurhana, Amiruddin, R., \& Abdullah, T. (2010). Faktor-faktor Yang Berhubungan Dengan Kejadian Tuberkulosis Paru Pada Masyarakat Di Provinsi Sulawesi Selatan 2007. Jurnal MKMI, 6(4), 204-209.

Nurjana, M. A. (2015). Faktor Risiko Terjadinya Tuberculosis Paru Usia Produktif (1549 Tahun) Di Indonesia. Media Libangkes, 25(3), 165-170.Susanto, H. A., Sakka, A., \& Tina, L.(2016). Prediksi Kejadian Penyakit Tb Paru BTA Positif Di Kota Kendari Tahun 2016-2020. JIMKesmas (Jurnal Ilmiah Kesehatan Masyarakat), $1(2), 1-14$.

Omu, F. E. (2016). Attitudes of Nursing Faculty Members and Graduates towards the Objective Structured Clinical Examination (OSCE). Open Journal Of Nursing, 6, 353-364. doi: http://doi.org/10.4236/ojn.2016.65037

Pangaribuan, L., Kristina, K., Perwitasari, D., Tejayanti, T., \& Lolong, D. B. (2020). Faktor-Faktor yang Mempengaruhi Kejadian Tuberkulosis pada Umur 15 Tahun ke Atas di Indonesia (Analisis Data Survei Prevalensi Tuberkulosis (SPTB) di Indonesia 2013-2014). Buletin Penelitian Sistem Kesehatan, 23(1), 10-17. doi: https://doi.org/10.22435/hsr.v23i1.2594 
Samsugito, I. (2018). Hubungan Jenis Kelamin dan Lama Kontak Dengan Kejadian Tuberkulosis Paru Di Rumah Sakit A. Wahab Sjahranie Samarinda. Jurnal Kesehatan Pasak Bumi Kalimantan, 1(1), 28-39.

Sarce \& Suarni. (2016). Faktor Yang Berhubungan Dengan Kejadian TB Paru Di RSUD Labuang Baji Makassar. Jurnal Ilmiah Kesehatan Diagnosis, 9(2), 11-21.

Sugiarto, \& Harijono. (2000). Peramalan Bisnis. Jakarta: PT. Gramedia Pustaka Utama.

Susanto, H. A. Sakka, A., \& Tina, L. (2016). Prediksi Kejadian Penyakit TB Paru BTA Positif di Kota Kendari Tahun 2016-2020. JIMKesmas (Jurnal Ilmiah Mahasiswa Kesehatan Masyarakat), 1(2), 1-14. 